\title{
Effect of Titanium Dioxide Nanoparticles on the Stereological Parameters of the Dentate Gyrus and the Morphology of Granular Hippocampal Neurons in Mice
}

\author{
Efecto de las Nanopartículas de Dióxido de Titanio sobre los Parámetros Estereológicos \\ del Giro Dentado y Morfología de las Neuronas Granulares del Hipocampo en Ratones
}

Sharare Rahnama ${ }^{1}$; Azam Hassanpour ${ }^{1}$; Maryam Yadegari $^{1,2}$; Morteza Anvari ${ }^{1}$ \& Mohammad Hosseini-sharifabad $^{1}$

RAHNAMA, S.; HASSANPOUR, A.; YADEGARI, M.; ANVARI, M.; HOSSEINI-SHARIFABAD, M. Effect of titanium dioxide nanoparticles on the stereological parameters of the dentate gyrus and the morphology of granular hippocampal neurons in mice. Int. $J$. Morphol.,38(6):1623-1630, 2020.

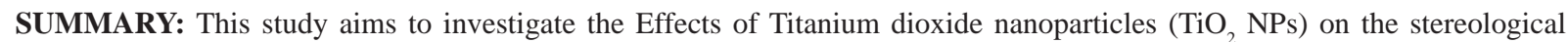
parameters in the dentate gyrus and the morphology of granular hippocampal neurons in adult mice. Adult male mice ( $\mathrm{n}=20$, weight average: $45 \mathrm{~g}$ ) were randomly divided into four groups including: group receiving saline (controls), low-dose (LD) $2.5 \mathrm{mg} / \mathrm{kg} \mathrm{TiO} \mathrm{TiO}{ }_{2}$ NPs, medium-dose (MD) $5 \mathrm{mg} / \mathrm{kg} \mathrm{TiO}_{2}$ NPs and high-dose (HD) $10 \mathrm{mg} / \mathrm{kg} \mathrm{TiO}{ }_{2} \mathrm{NPs}$, daily using gavage for 35 days. To estimate the volume of the hippocampus, dentate gyrus, and sub-layers of dentate gyrus the Cavalieri principle was used. The physical dissector was used to determine the numerical density of dentate gyrus granular cells. For analyzing the morphology of dentate gyrus granular cells the qualitative Golgi staining was used. Our data showed that the total volume of the hippocampus, dentate gyrus and its sublayers including molecular, granular and polymorph in $\mathrm{TiO}_{2}$ treated mice decreased significantly compared to the control group. Moreover, the total number and numerical density of dentate gyrus granular sub layer cells showed a significant reduction in all three experimental groups compared to the control group. The granular cells of the dentate gyrus had shorter dendritic length and decreased dendritic branches in the $\mathrm{TiO}_{2}$-treated in comparison with the control mice. These data can justify the disorders related to memory, learning and hippocampus neurons damages due to using of $\mathrm{TiO}_{2}$ NPs.

KEY WORDS: TiO2; Stereology; Hippocampus; Dentate gyrus.

\section{INTRODUCTION}

Titanium dioxide nanoparticles $\left(\mathrm{TiO}_{2} \mathrm{NPs}\right)$ have been widely used, including the cosmetics industry, medicine, food additives, paint industry, confectionary products, agriculture, weather purification, etc. (Powell et al., 2010; Skocaj et al., 2011; Weir et al., 2012). However, many studies have investigated the disadvantages of $\mathrm{TiO}_{2} \mathrm{NPs}$. Several reports showed the negative effects of $\mathrm{TiO}_{2}$ NPs on the mice's brain and hippocampus. It has been proven that the exposure of pregnancy/lactating mice to nano- $\mathrm{TiO}_{2}$ lead to thinning of cerebral and cerebellar cortex, and pyramidal cell layer in hippocampus, decrease in number of neurons per unit area of cerebrum, dysplasia of neurites in hippocampal pyramidal cells, and decrease in learning and memory of mice offspring (Ze et al., 2014; Mohammadipour et al., 2016; Hong et al., 2018). Also, investigation of the hippocampus in mice offspring that exposed to $\mathrm{TiO}_{2} \mathrm{NPs}$ during pregnancy showed a decrease of dendritic length in hippocampal CA1 neurons and $\mathrm{TiO}_{2}$ NPS accumulation in neurons of hippocampus neurons, also caused apoptosis, severe autophagy and ROS (reactive oxygen species) production (Zhou et al., 2017). Another study showed similar data in which $\mathrm{TiO}_{2}$ NPs can penetrate the blood-brain barrier and accumulate in the cortex of the brain and the hippocampus, causing activation of microglia neuroinflammation and signaling pathway of brain inflammation, ROS generation, toxicity and cell death in vitro and in vivo (Czajka et al., 2015; Song et al., 2015; Hong et al., 2017). Moreover, studies demonstrated that $\mathrm{TiO}_{2} \mathrm{NPs}$ caused apoptosis in the hippocampus and impaired the spatial recognition memory ability (Hu et al., 2010; Bideskan et al., 2017; He et al., 2018).

\footnotetext{
${ }^{1}$ Anatomy and Cell Biology Department, Medical faculty, Shahid Sadoughi University of Medical Sciences, Yazd, Iran.

${ }^{2}$ Neurobiomedical Research Center, Medical faculty, Shahid Sadoghi University of Medical Sciences, Yazd, Iran.
} 
Despite several studies that examine the adverse effects of $\mathrm{TiO}_{2}$ NPs on the structure of the hippocampus qualitatively, there are a few studies that quantitatively examine its effects on the structure of the hippocampus. So, this study aimed to provide estimates of the total number of granular neurons, the volume of the hippocampus, dentate gyrus and sublayers of dentate gyrus and morphology of granular neurons of the dentate gyrus influenced by $\mathrm{TiO}_{2}$ NPs exposure in mice by stereological methods.

\section{MATERIAL AND METHOD}

Animal and treatment. In this experimental study, Twenty adult male mice were randomly assigned from the animal house of the institute of reproductive sciences that age average 10-12 weeks and weight average $45 \mathrm{~g}$ were used. Animals were maintained in the same cages under standard conditions, $12 \mathrm{~h} \mathrm{light/dark} \mathrm{cycle} \mathrm{and} \mathrm{at}$ temperature $23{ }^{\circ} \mathrm{C} \pm 2{ }^{\circ} \mathrm{C}$ and humidity of $55 \% \pm 5 \%$. Water and food were easy to access ad libitum. The mice were randomly divided into four groups including a control group and three experimental groups were treated whit 2/5, 5 and $10 \mathrm{mg}$ per $\mathrm{kg} \mathrm{TiO}_{2}$ NPs. All three were treated whit $\mathrm{TiO}_{2}$ NPs as a suspension via gavage for 35 days and the sham group received normal saline via gavage.

Histological procedures. For animal anesthesia, ketamine (Merk, Germany), phosphate-buffered solution of $10 \%$ formaldehyde were used for perfusion and were fixed in $1 \%$ glutaraldehyde. After perfusion, the brains were removed carefully from the skull by craniotomy and each brain was separated from the midsagittal line and divided into hemispheres. For estimating the volume of the hippocampus, dentate gyrus and sub-layers of the dentate gyrus and the numerical density of dentate gyrus granular cells, one hemisphere was chosen accidentally, and the other was utilized for morphological analysis of dentate gyrus granular neurons. After the samples were embedded the serial coronal sections $(5 \mu \mathrm{m}$ for estimating the volume, $30 \mathrm{~mm}$ for the number of neurons and $50 \mu \mathrm{m}$ for the morphology of neurons) were sliced from the full thickness of the hippocampus using a rotatory microtome (litez Germany). From the tissue sections cut, 12 pair sections were systematically and uniformly sampled with a random start in the first 80 sections. For estimating the number of neurons and the volume, the slide-mounted sampled sections were stained with routine hematoxylin and eosin (Sigma, USA). For estimating the morphology of neurons in the granular layer of dentate gyrus, the tissue sections were stained with silver nitrate staining (Merck, Germany).
Hematoxylin and Eosin staining. Before staining, the slide-mounted sampled sections were placed in two xylene containers each one for 10 min to deparaffinized. In the following, rehydration in $96 \%, 80 \%, 70 \%$ and $50 \%$ ethanol each one for $2 \mathrm{~min}$ and distilled water for $1 \mathrm{~min}$. Subsequently, the sections were stained in hematoxylin solution for $5 \mathrm{~min}$ and then rinsed quickly in running water. For decolorization, $75 \%$ ethyl alcohol was used for a few seconds. The sections were then stained in eosin solution for 2 min and then dehydrated in $50 \%, 70 \%, 80 \%$ and $96 \%$ ethanol for 5 min and mounted in Entellan (Merck, Germany) (Cardiff et al., 2014).

Silver nitrate staining. The slides of hippocampal samples were stained with silver nitrate solution. At first, the slides were placed in heated silver nitrate solution (40 ${ }^{\circ} \mathrm{C}$ ) for $15 \mathrm{~min}$. Then the slides were placed in distilled water for $1 \mathrm{~min}$, into heated ammonia silver nitrate solution $\left(40{ }^{\circ} \mathrm{C}\right.$ ) for $30 \mathrm{~min}$, in ammonia hydroxide solution to stop reaction and was washed in distilled water, then, into Sodium thiosulphate solution for $5 \mathrm{~min}$ and was washed in distilled water, at the end, the processes of dehydrating, clearing and mounted in Entellan were performed.

\section{Stereology assessment}

Estimation of tissue volume. For volumetric analysis of the hippocampus, dentate gyrus and sublayers of the dentate gyrus, the photography was performed under the $5 \times$ objective lens (Olympus, Japan), and total magnification was $50 \times$. The volume of the hippocampus, dentate gyrus, and sublayers of the dentate gyrus were estimated by using Cavalieri's principle method (Sarbishegi et al., 2016; Dortaj et al., 2018). Cavalieri's Principle (Gundersen et al., 1988) is a method for determining the reference volumes of the hippocampal, dentate gyrus and sublayers of dentate gyrus by using the point-counting grid. A transparent grid was randomly placed over the sublayers of each sampled section. Points that hit each layer of the dentate gyrus were counted. The reference volume was calculated by the following formula: $\mathrm{Nv}=\sum \mathrm{Q} / \mathrm{N}($ dis $) \times \mathrm{V}($ dis $)$

Where $\sum$ pi is the total number of grid points appeared in sections, A (pi) is the area associated with each grid point, $t$ is the known distance between sections and $\mathrm{M} 2$ is the magnification.

Estimation of cell density. The granular cell density in the granular layer of the dentate gyrus was determined via the physical dissector method (Miki et al., 2005; Hadizade Asar et al., 2016) by the following formula:

$\mathrm{Nv}=\sum \mathrm{Q} / \mathrm{N}($ dis $) \times \mathrm{V}($ dis $)$ 

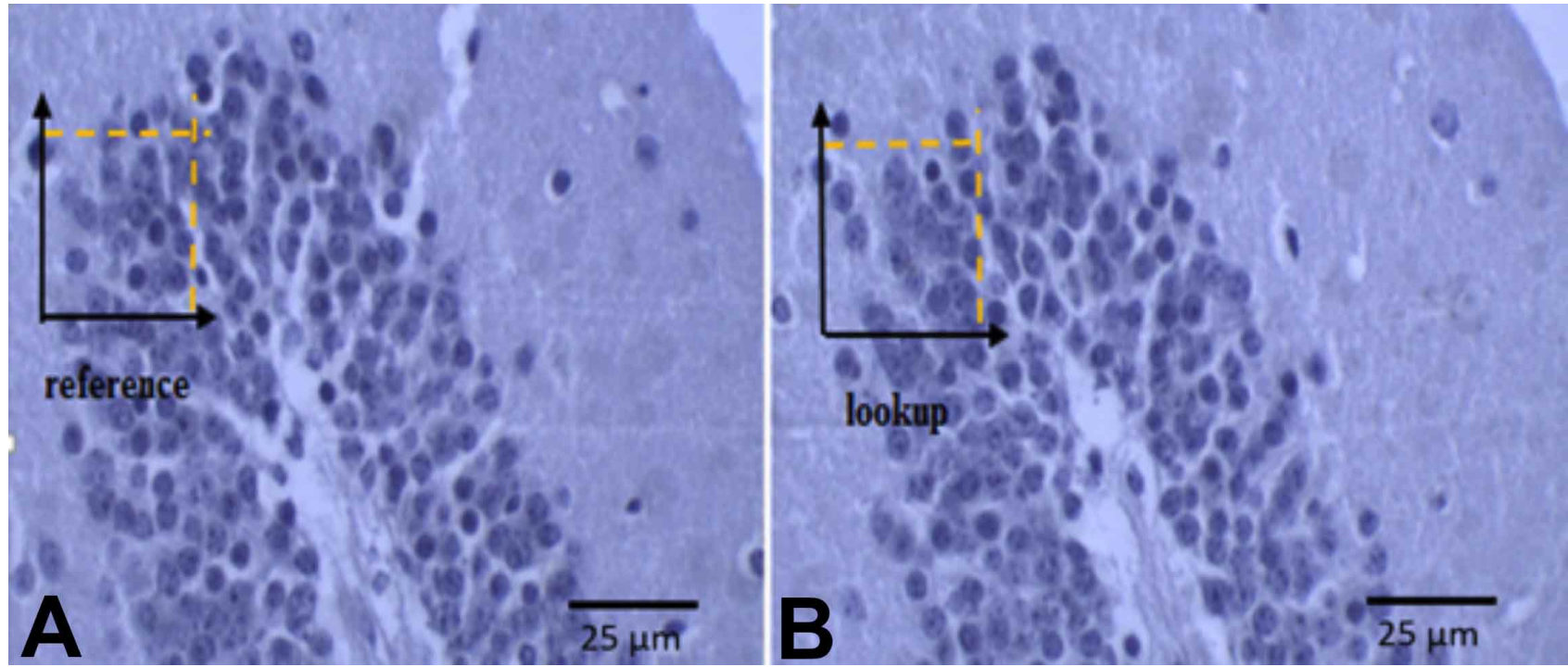

Fig. 1. Physical disector grid showing included lines (continues line) and forbidden lines (dotted line) (H\&E staining, 400×).

Where $\Sigma \mathrm{Q}$ is the number of granular cells counted (nucleolus as counting units) in each dissector frame of sampled sections, $\mathrm{N}(\mathrm{dis})$ is the sum of all counted dissector frames, $\mathrm{V}(\mathrm{dis})$ is the volume of dissector frame: $\mathrm{V}(\mathrm{dis})=$ A(frame $) \times h$

Where A (frame) is the known area associated with each dissector frame and $\mathrm{h}$ is the height of section and was equal to the section thickness. For the estimation of the density of granular cells of the dentate gyrus, two serial sections were observed with a $40 \times$ objective lens and total magnification was $400 \times x$. If the nucleolus of a cell was located entirely inside the counting frame or contact with the inclusion lines of the one section (reference section) were counted, whereas those in touch with the exclusion lines of the adjacent serial section (look-up section) were excluded (Fig. 1). The total number of pyramidal cells was estimated by multiplying the measures of the reference volume "V (ref)" of the sublayers by the measures of the numerical density, "Nv".

Statistical analysis. Data were expressed as mean \pm standard deviation (SD). Statistical comparisons were performed using one-way ANOVA followed by Tukey post hoc test. All statistical analysis was carried out using graph pad prism software, version 19. Differences were defined as $\mathrm{p}<0.05$.

\section{RESULTS}

Data showed $\mathrm{TiO}_{2}$-treated mice had significantly thinner volumes than controls in the total volume of the hippocampus, dentate gyrus and subfields of the dentate gyrus (Figs. 2 to 6 and 9). A comparison of the five groups showed a decrease in both total number (Fig. 8) and the numerical density of granular cells of the dentate gyrus of the hippocampus in experimental groups compared with controls (Fig. 7). The results of the qualitative analysis of granular cells of dentate gyrus also demonstrated that in these neurons, the dendritic length was shorter in the $\mathrm{TiO}_{2}-$ treated in comparison with the control mice (Fig. 10).

Total volume of the hippocampus in mice. Stereological investigation indicated that the total volume of the hippocampus in $\mathrm{TiO}_{2}$-treated groups was de-creased compared with the control group. The Low dose group was de-creased compared to the control group with $\mathrm{P}<0.05$, mediate dose group was de-creased compared to control group with $\mathrm{P}<0.001$, high dose group was de-creased compared to control group with $\mathrm{P}<0.001$ (Fig. 2).

Total volume of the dentate gyrus in mice. Stereological investigation indicated that the volume of the dentate gyrus in $\mathrm{TiO}_{2}$-treated groups was de-creased compared with the control group. The mediate dose group $(\mathrm{P}<0.01)$ was decreased compared with the control group. High dose group $\mathrm{P}<0.001$ was de-creased compared with the control group (Fig. 3).

Volume of the molecular layer of the dentate gyrus. Stereological investigation indicated that the volume of the dentate gyrus in $\mathrm{TiO}_{2}$-treated groups was de-creased compared with the control group. The mediate dose group $(\mathrm{P}<0.05)$ was decreased compared to the control group. High dose group was $(\mathrm{P}<0.001)$ decreased compared with the control group (Fig. 4). 


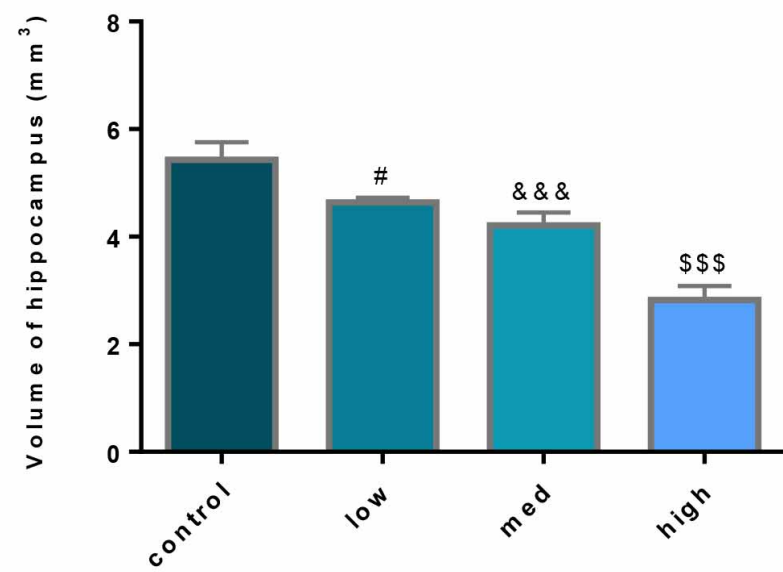

Fig. 2. Bar graphs showing the effect of $\mathrm{TiO}_{2}$ NPs on the total volume of the hippocampus. \# Low dose group compared to the control group with $\mathrm{P}<0.05$. \&\&\& mediate dose group compared to the control group with $\mathrm{P}<0.001$. $\$ \$$ high dose group compared to the control group with $\mathrm{P}<0.001$

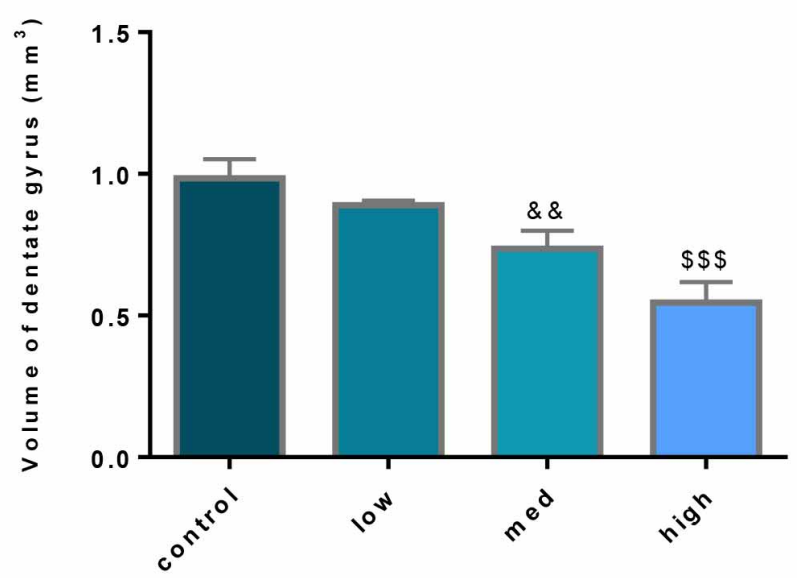

Fig. 3. Bar graphs showing the effect of $\mathrm{TiO}_{2} \mathrm{NPs}_{\text {on }}$ the volume of the dentate gyrus. \&\& mediate dose group compared to the control group with $\mathrm{P}<0.01$. $\$ \$ \$$ high dose group compared to the control group with $\mathrm{P}<0.001$

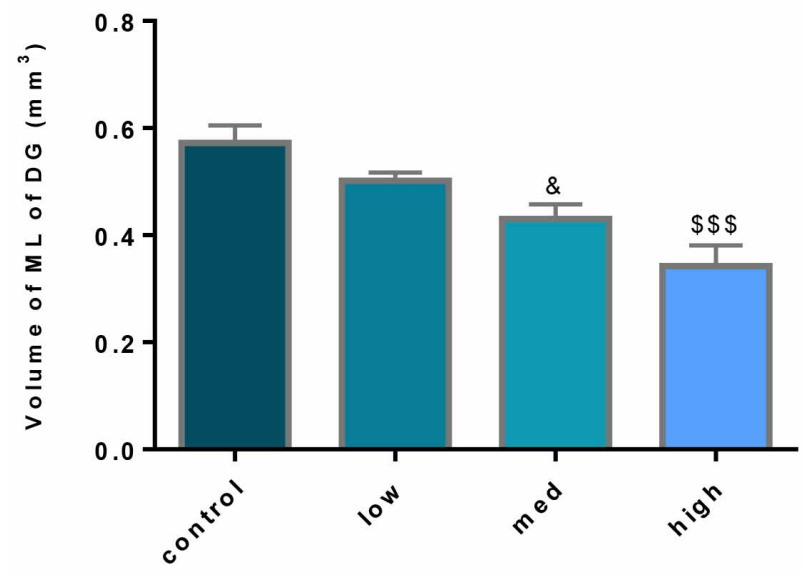

Fig. 4. Bar graphs showing the effects of $\mathrm{TiO}_{2} \mathrm{NPs}$ on the volume of the molecular layer. \& mediate dose group compared to the control group with $\mathrm{P}<0.05$. $\$$ high dose group compared to the control group with $\mathrm{P}<0.001$.
Volume of the granular layer of the dentate gyrus. Stereological investigation indicated that the volume of the granular layer of the dentate gyrus in $\mathrm{TiO}_{2}$-treated groups was de-creased compared with the control group. The mediate dose group $(\mathrm{P}<0.01)$ was decreased compared to the control group. High dose group was $(\mathrm{P}<0.001)$ decreased compared with the control group (Fig. 5).

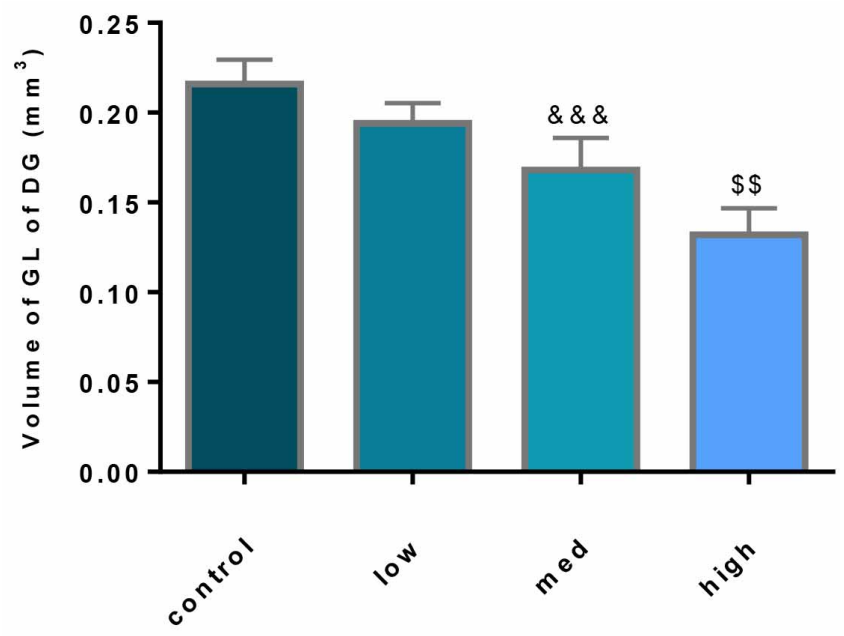

Fig. 5. Bar graph showing the effect of $\mathrm{TiO}_{2}$ NPs on the granular layer. \&\&\& mediate dose group compared to the control group with $\mathrm{P}<0.001$. \$ $\$$ high dose group compared to the control group with $\mathrm{P}<0.01$.

Volume of polymorph layer of the dentate gyrus. Stereological investigation indicated that the volume of the polymorph layer of the dentate gyrus in $\mathrm{TiO}_{2}$-treated groups was de-creased compared with the control group. The low dose group $(\mathrm{P}<0.001)$ was decreased compared with the control group. The mediate dose group $(\mathrm{P}<0.001)$ were decreased compared to the control group. High dose group was $(\mathrm{P}<0.001)$ decreased compared with the control group (Fig. 6).

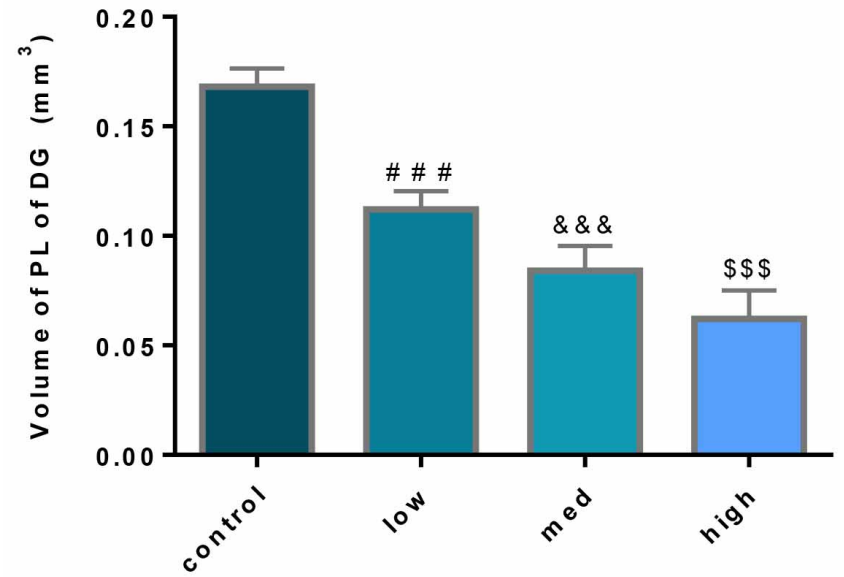

Fig. 6. Bar graph showing the effects of $\mathrm{TiO}_{2}$ NPs on the polymorph. \#\#\# Low dose group compared to the control group with $\mathrm{P}<0.001$. $\& \& \&$ mediate dose group compared to the control group with $\mathrm{P}<0.001$. $\$ \$ \$$ high dose group compared to the control group with $\mathrm{P}<0.001$. 
Numerical density of dentate gyrus granular cells. The results showed that $\mathrm{TiO}_{2}$ affected the hippocampus and decreased the number of granular cells. The Low dose group $(\mathrm{P}<0.001)$, mediate dose group $(\mathrm{P}<0.001)$ and high dose group $(\mathrm{P}<0.001)$ were decreased compared with the control group (Fig. 7).

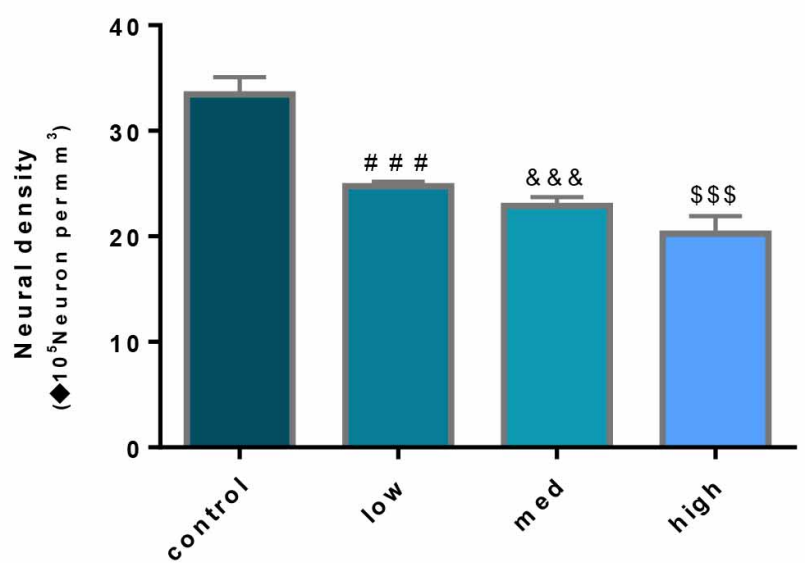

Fig.7. Bar graphs showing the effect of $\mathrm{TiO}_{2} \mathrm{NPs}$ on the numerical density of dentate gyrus granular cells. \#\#\# Low dose group compared to the control group with $\mathrm{P}<0.001$. \&\&\& mediate dose group compared to the control group with $\mathrm{P}<0.001$. $\$ \$ \$$ high dose group compared to the control group with $\mathrm{P}<0.001$.
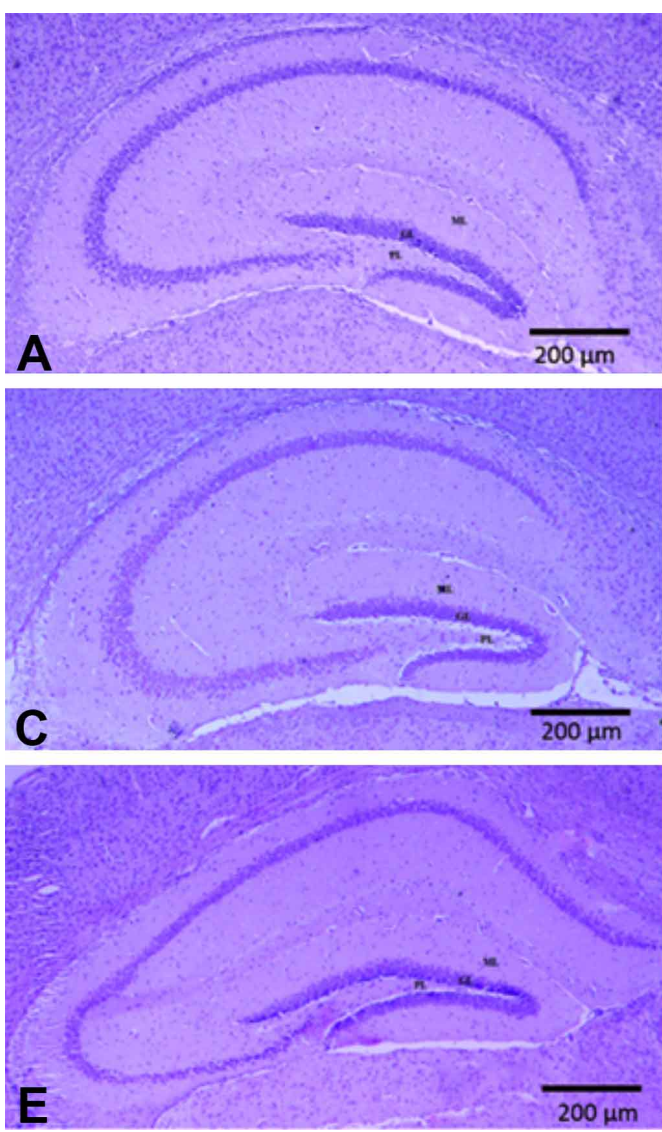

Total neuron of the granular layer of the dentate gyrus. The results showed that $\mathrm{TTiO}_{2}$ affected the hippocampus and decreased the total neuron of the granular layer of the dentate gyrus. The low dose group $(\mathrm{P}<0.001)$, mediate dose group $(\mathrm{P}<0.001)$ and high dose group $(\mathrm{P}<0.001)$ was decreased compared with the control group (Fig. 8).

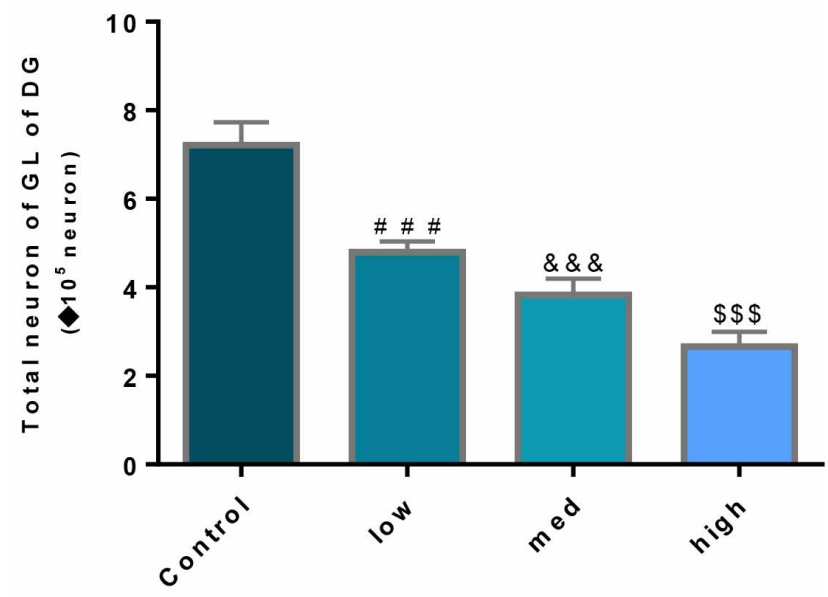

Fig.8. Bar graphs showing the effect of $\mathrm{TiO}_{2} \mathrm{NPs}_{\text {on }}$ the numerical neuron of dentate gyrus granular cells. \#\#\# Low dose group compared to the control group with $\mathrm{P}<0.001$. \&\&\& mediate dose group compared to the control group with $\mathrm{P}<0.001$. $\$ \$ \$$ high dose group compared to the control group with $\mathrm{P}<0.001$.
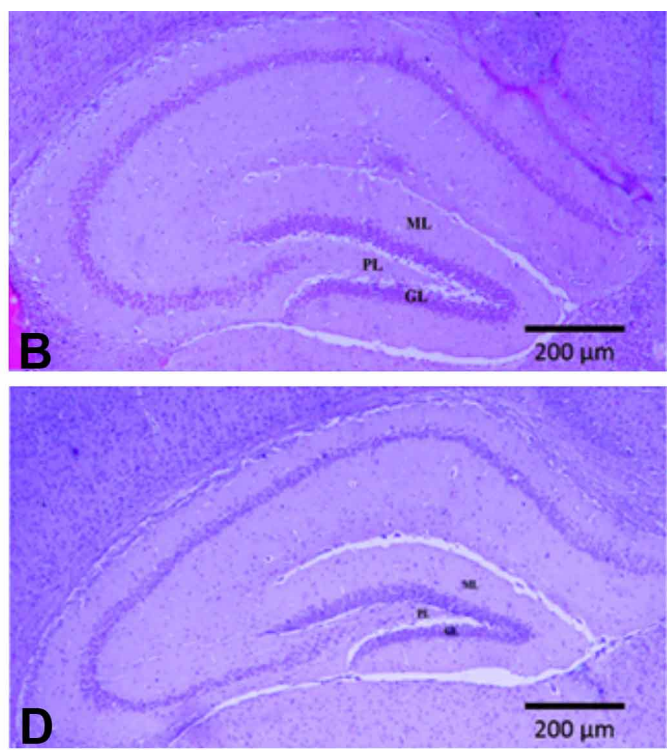

Fig. 9. Representative photomicrographs of a hematoxylin-eosin stained that showing the total volume of the hippocampus, dentate gyrus and sublayers of dentate gyrus decreased in experimental groups compared to the control group. A. Control group; B. Sham group; C. Low dose group; D. Mediate group; E. High dose group. ML. Molecular layer; GL. Granular layer; PL. Polymorph layer. H \& E staining, 50×. 

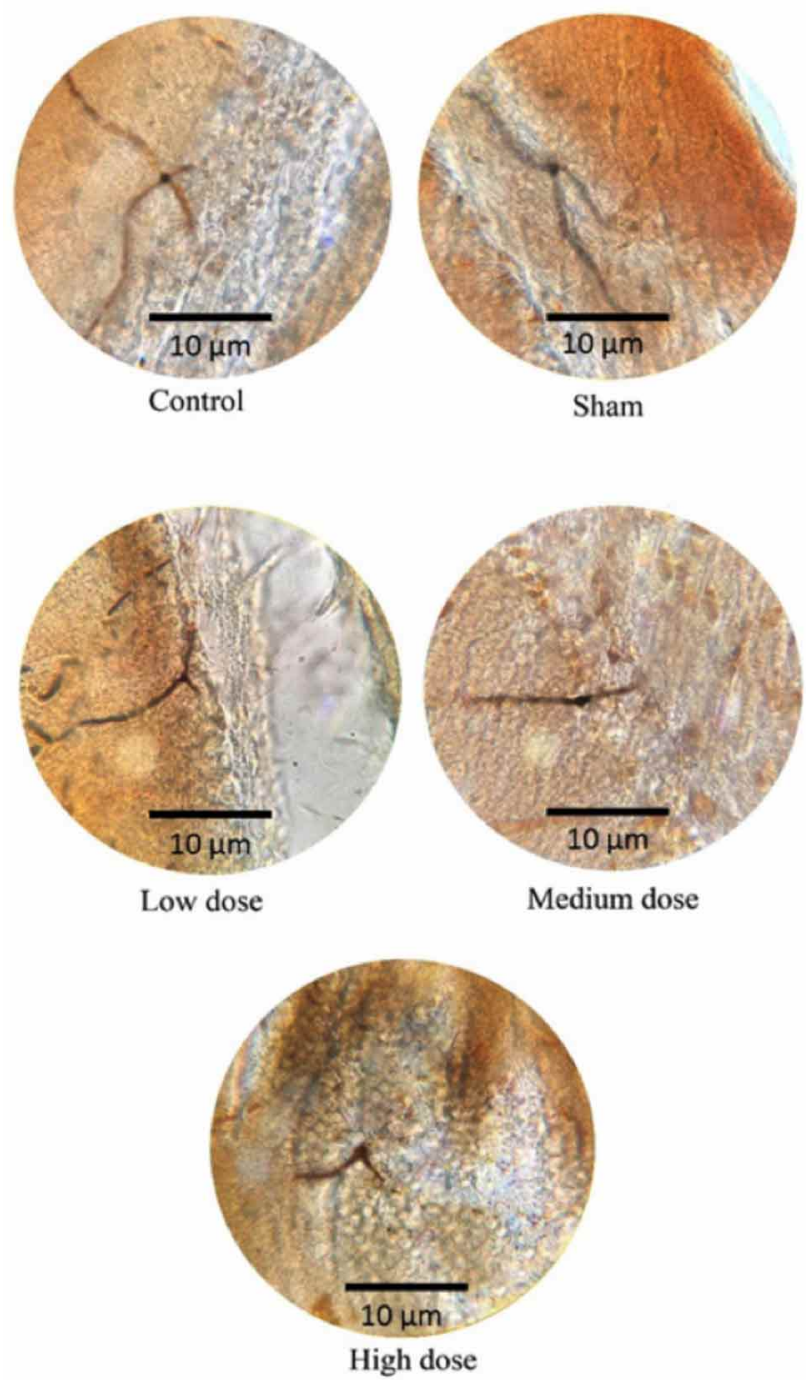

Fig.10. photomontages of Golgi-impregnated dentate gyrus granular cells. Observe the decrease in dendritic length in $\mathrm{TiO}_{2}-$ treated mice compared to controls. Golgi staining, 100×.

\section{DISCUSSION}

In the current study, the effects of titanium dioxide nanoparticles on the stereological parameters of the dentate gyrus and the morphology of granular hippocampal neurons in mice were evaluated. In this study $2 / 5,5$ and $10 \mathrm{mg} / \mathrm{kg}$ $\mathrm{TiO}_{2}$ NPs $(5 \mathrm{~nm})$ suspensions were given to the mice every day for 35 days. The results of this study by using the stereological methods were: administration of $\mathrm{TiO}_{2} \mathrm{NPs}$ reduced total hippocampal volume, dentate gyrus and dentate gyrus sublayers in experimental groups compared to the control group. Also, the results of this study indicated that the numerical density and the total number of granular neurons in the granular layer of hippocampal dentate gyrus decreased in the three experimental groups compared to the control group. Also, Golgi staining demonstrated that dendritic length and dendritic branching number of granular cells of the dentate gyrus in the nano- $\mathrm{TiO}_{2}$ exposed groups with increasing dose were decreased. Also, Golgi-stained dentate gyrus granular neurons revealed that dendritic length and dendritic branching number with increasing dose were decreased in $\mathrm{TiO}_{2}$-treated groups compared with control. The results of our study have corresponded with the results of a study conducted by Hong et al. (2018). They suggested that exposure to $\mathrm{TiO}_{2} \mathrm{NPs}$ has led to thinning of the cerebral cortex and cerebellar cortex, decreasing the number of neurons of the brain, nerve dysplasia in hippocampal pyramidal cells, decreasing the layer of hippocampal pyramidal cells and decreasing learning and memory in mice (Hong et al., 2018). In the study of Hong et al. (2018), the number of cells in the hippocampal pyramidal layer was studied but in the present study, the number of granular cells of the hippocampal dentate gyrus was investigated.

Reduction in the volume of the molecular layer of the dentate gyrus in experimental groups may be the result of shortening of the neuronal fractions in this layer, because the molecular layer is composed of neuronal fractures.

Zhou et al. (2017) reported exposure to $\mathrm{TiO}_{2} \mathrm{NPs}$ due to the absence of axonal outgrowth and decreased dendritic filament length, dendritic branching number, and dendritic spine density in mice hippocampal pyramidal neurons (Hu et al., 2010). This study confirms this.

Reduction in the volume of the granular layer of dentate gyrus may be due to the decrease in the number of neurons in this layer. Based on previous studies exposure to $\mathrm{TiO}_{2} \mathrm{NPs}$ can cause nerve dysplasia in hippocampal pyramidal cells and decrease the layer of hippocampal pyramidal cells (Hong et al., 2018). Reduction in the volume of the polymorph layer of dentate gyrus can be attributed to the decrease in proliferating neurons in this layer. Consistent with our results, it was described by Mohammadipour et al. (2014) that $\mathrm{TiO}_{2}-$ administrated mice showed $\mathrm{TiO}_{2}$ NPs have a negative effect on neurogenesis in the mice offspring hippocampus. Shortening of dendritic length and reduction of dendritic branching number of granular neurons of mice hippocampal dentate gyrus are probably due to apoptosis, ROS production, and oxidative stress. According to previous studies, $\mathrm{TiO}_{2} \mathrm{NPs}$ due to shortening of the dendritic length of mice hippocampal pyramidal neurons (Zhou et al., 2017). Also, $\mathrm{TiO}_{2} \mathrm{NPs}_{\text {due to }}$ the absence of axonal outgrowth, and decreased dendritic filament length, dendritic branching number, and dendritic spine density in mice hippocampal pyramidal neurons (Zhou et al., 2019). This may be the reason for the decrease in Neuronal consequences in our study. 
Based on previous studies, exposure to $\mathrm{TiO}_{2} \mathrm{NPs}$ can cause inflammation in microglia, ROS production and activation of signaling pathways involved in brain inflammation (Czajka et al.). Also, these nanoparticles can be accumulated in the brain, causing oxidative stress and overproduction of glial cells, tissue necrosis, and apoptosis in the hippocampus (Ze et al., 2013). Furthermore, Renping $\mathrm{Hu}$ et al. (2011) investigated the molecular mechanism of apoptosis in the hippocampus of mice exposed to $\mathrm{TiO}_{2} \mathrm{NPs}$ for 60 days orally and reported that these nanoparticles induced apoptosis in the hippocampus and can impair spatial memory recognition. A previous study reported that exposure to $\mathrm{TiO}_{2}$ NPs resulted in the upregulation of Cyt $\mathrm{C}$, caspase-3, and $\mathrm{C}$ Jun expression in neuronal apoptosis and a decrease in neuronal dendrite length in offspring mice (Zhou et al., 2019).

\section{CONCLUSION}

We have demonstrated that exposure to $\mathrm{TiO}_{2}$ NPs has significant effects on the total volume of total hippocampal volume, dentate gyrus and dentate gyrus sublayers and the granular cell numbers in the dentate gyrus. This data can justify the disorders related to memory, learning and hippocampus neuron damage due to the use of $\mathrm{TiO}_{2}$ NPs.

ETHICS APPROVAL. All experiments were conducted according to relevant guidelines and were approved by the Ethics Committee of the Shahid Sadoughi University of Medical Sciences (Registration number: IR.SSU. MEDICINE.REC.1398.327).

ACKNOWLEDGMENTS. This article was extracted from a thesis written by Sharare Rahnama, MSc. candidate of Anatomy and financially supported by Shahid Sadoughi University of Medical Sciences and Health Services, Yazd, Iran. We would like to thank the Department of Anatomy and Cell Biology for their official cooperation.

RAHNAMA, S.; HASSANPOUR, A.; YADEGARI, M.; ANVARI, M.; HOSSEINI-SHARIFABAD, M. Efecto de las nanopartículas de dióxido de titanio sobre los parámetros estereológicos del giro dentado y morfología de las neuronas granulares del hipocampo en ratones. Int. J. Morphol., 38(6):16231630,2020

RESUMEN: En este estudio se analizaron los efectos de las nanopartículas de dióxido de titanio $\left(\mathrm{TiO}_{2} \mathrm{NP}\right)$ sobre los parámetros estereológicos en el giro dentado y la morfología de las neuronas granulares del hipocampo en ratones adultos. Se divi- dieron aleatoriamente ratones machos adultos $(n=20$, promedio de peso: $45 \mathrm{~g}$ ) en cuatro grupos: grupo que recibió solución salina (controles), dosis baja (LD) $2,5 \mathrm{mg} / \mathrm{kg} \mathrm{NP}$ de $\mathrm{TiO}_{2}$, dosis media (MD) $5 \mathrm{mg} / \mathrm{kg}$ de $\mathrm{NP}$ de $\mathrm{TiO}_{2}$ y dosis altas (HD) de $10 \mathrm{mg} / \mathrm{kg}$ de $\mathrm{NP}$ de $\mathrm{TiO}_{2}$, por vía utilizando sonda durante 35 días. Para estimar el volumen del hipocampo, el giro dentado y las subcapas del giro dentado se utilizó el principio de Cavalieri. Se utilizó el disector físico para determinar la densidad numérica de las células granulares del giro dentado. Para analizar la morfología de las células granulares del giro dentado se usó la tinción cualitativa de Golgi. Nuestros datos mostraron que el volumen total del hipocampo, el giro dentado y sus subcapas, incluyendo la molecular, granular y polimorfos, en ratones tratados con $\mathrm{TiO}_{2}$, disminuyó significativamente en comparación con el grupo de control. Además, el número total y la densidad numérica de las células de la subcapa granular del giro dentado mostró una reducción significativa en los tres grupos experimentales en comparación con el grupo control. Las células granulares del giro dentado tenían una longitud dendrítica menor y ramas dendríticas disminuidas en los ratones tratados con $\mathrm{TiO}_{2}$ en comparación con los ratones del grupo control. Estos datos pueden justificar los trastornos relacionados con la memoria, el aprendizaje y los daños en las neuronas del hipocampo debido al uso de $\mathrm{NP}$ de $\mathrm{TiO}_{2}$.

PALABRAS ClaVE: $\mathrm{TiO}_{2}$; Estereología; Hipocampo; Giro dentado.

\section{REFERENCES}

Bideskan, A. E.; Mohammadipour, A.; Fazel, A.; Haghir, H.; Rafatpanah, H.; Hosseini, M. \& Rajabzadeh, A. Maternal exposure to titanium dioxide nanoparticles during pregnancy and lactation alters offspring hippocampal mRNA BAX and Bcl-2 levels, induces apoptosis and decreases neurogenesis. Exp. Toxicol. Pathol., 69(6):329-37, 2017.

Cardiff, R. D.; Miller, C. H. \& Munn, R. J. Manual hematoxylin and eosin staining of mouse tissue sections. Cold Spring Harb. Protoc., 2014(6):655-8, 2014.

Czajka, M.; Sawicki, K.; Sikorska, K.; Popek, S.; Kruszewski, M. \& KapkaSkrzypczak, L. Toxicity of titanium dioxide nanoparticles in central nervous system. Toxicol. In Vitro, 29(5):1042-52, 2015.

Dortaj, H.; Yadegari, M.; Abad, M. H. S.; Sarcheshmeh, A. A. \& Anvari, M. Stereological method for assessing the effect of vitamin C administration on the reduction of acrylamide-induced neurotoxicity. Basic Clin. Neurosci., 9(1):27-34, 2018.

Gundersen, H. J.; Bendtsen, T. F.; Korbo, L.; Marcussen, N.; Møller, A.; Nielsen, K.; Nyengaard, J. R.; Pakkenberg, B.; Sørensen, F. B.; Vesterby, A.; et al. Some new, simple and efficient stereological methods and their use in pathological research and diagnosis. APMIS, 96(5):37994, 1988.

Hadizade Asar, S.; Hosseini-Sharifabad, M. \& Yadegari, M. A stereological study on hippocampal subfields following administration of methamphetamine in male mice. Int. J. Med. Lab., 3(4):270-81, 2016.

He, Q.; Zhou, X.; Liu, Y.; Gou, W.; Cui, J.; Li, Z.; Wu, Y. \& Zuo, D. Titanium dioxide nanoparticles induce mouse hippocampal neuron apoptosis via oxidative stress- and calcium imbalance-mediated endoplasmic reticulum stress. Environ. Toxicol. Pharmacol., 63:6-15, 2018.

Hong, F.; Yu, X.; Wu, N. \& Zhang, Y. Q. Progress of in vivo studies on the systemic toxicities induced by titanium dioxide nanoparticles. Toxicol. Res. (Camb.), 6(2):115-33, 2017. 
Hong, F.; Zhou, Y.; Ji, J.; Zhuang, J.; Sheng, L. \& Wang, L. Nano-TiO2 inhibits development of the central nervous system and its mechanism in offspring mice. J. Agric. Food Chem., 66(44):11767-74, 2018.

Hu, R.; Gong, X.; Duan, Y.; Li, N.; Che, Y.; Cui, Y.; Zhou, M.; Liu, C.; Wang, H. \& Hong, F. Neurotoxicological effects and the impairment of spatial recognition memory in mice caused by exposure to $\mathrm{TiO}_{2}$ nanoparticles. Biomaterials, 31(31):8043-50, 2010.

Hu, R.; Zheng, L.; Zhang, T.; Gao, G.; Cui, Y.; Cheng, Z.; Cheng, J.; Hong, M.; Tang, M. \& Hong, F. Molecular mechanism of hippocampal apoptosis of mice following exposure to titanium dioxide nanoparticles. J. Hazard. Mater, 191(1-3):32-40, 2011

Miki, T.; Satriotomo, I.; Li, H. P.; Matsumoto, Y.; Gu, H.; Yokoyama, T.; Lee, K. Y.; Bedi, K. S. \& Takeuchi, Y. Application of the physical disector to the central nervous system: estimation of the total number of neurons in subdivisions of the rat hippocampus. Anat. Sci. Int., 80(3):153-62, 2005

Mohammadipour, A.; Fazel, A.; Haghir, H.; Motejaded, F.; Rafatpanah, H.; Zabihi, H.; Hosseini, M. \& Bideskan, A. E. Maternal exposure to titanium dioxide nanoparticles during pregnancy; impaired memory and decreased hippocampal cell proliferation in rat offspring. Environ. Toxicol. Pharmacol., 37(2):617-25, 2014.

Mohammadipour, A.; Hosseini, M.; Fazel, A.; Haghir, H.; Rafatpanah, H.; Pourganji, M. \& Bideskan, A. E. The effects of exposure to titanium dioxide nanoparticles during lactation period on learning and memory of rat offspring. Toxicol. Ind. Health, 32(2):221-8, 2016.

Powell, J. J.; Faria, N.; Thomas-McKay, E. \& Pele, L. C. Origin and fate of dietary nanoparticles and microparticles in the gastrointestinal tract. J. Autoimmun., 34(3):J226-33, 2010.

Sarbishegi, M.; Heidari, Z.; Mahmoudzadeh-Sagheb, H.; Valizadeh, M. \& Doostkami, M. Neuroprotective effects of Withania coagulans root extract on CA1 hippocampus following cerebral ischemia in rats. Avicenna J. Phytomed., 6(4):399-409, 2016.

Skocaj, M.; Filipic, M.; Petkovic, J. \& Novak, S. Titanium dioxide in our everyday life; is it safe? Radiol. Oncol., 45(4):227-47, 2011.

Song, B.; Liu, J.; Feng, X.; Wei, L. \& Shao, L. A review on potential neurotoxicity of titanium dioxide nanoparticles. Nanoscale Res. Lett., 10:342, 2015.

Weir, A.; Westerhoff, P.; Fabricius, L. \& von Goetz, N. Titanium dioxide nanoparticles in food and personal care products. Environ. Sci. Technol., 46(4):2242-50, 2012.

Ze, Y.; Hu, R.; Wang, X.; Sang, X.; Ze, X.; Li, B.; Su, J.; Wang, Y.; Guan, N.; Zhao, X.; et al. Neurotoxicity and gene-expressed profile in braininjured mice caused by exposure to titanium dioxide nanoparticles. $J$. Biomed. Mater. Res. A, 102(2):470-8, 2014.

Ze, Y.; Zheng, L.; Zhao, X.; Gui, S.; Sang, X.; Su, J.; Guan, N.; Zhu, L.; Sheng, L.; Hu, R.; et al. Molecular mechanism of titanium dioxide nanoparticles-induced oxidative injury in the brain of mice. Chemosphere, 92(9):1183-9, 2013.

Zhou, Y.; Hong, F.; Tian, Y.; Zhao, X.; Hong, J.; Ze, Y. \& Wang, L. Nanoparticulate titanium dioxide-inhibited dendritic development is involved in apoptosis and autophagy of hippocampal neurons in offspring mice. Toxicol. Res. (Camb.), 6(6):889-901, 2017.

Zhou, Y.; Ji, J.; Chen, C. \& Hong, F. Retardation of axonal and dendritic outgrowth is associated with the MAPK signaling pathway in offspring mice following maternal exposure to nanosized titanium dioxide. $J$. Agric. Food Chem., 67(9):2709-15, 2019.
Corresponding author:

Mohammad Hosseini-Sharifabad

Anatomy and Cell Biology Department

Medical Faculty

Shahid Sadoughi University of Medical Sciences

Department of Biology and Anatomical Sciences

Shohadaie Gomnam Boulevard

Yazd

IRAN

Email: mhosseini81@yahoo.com

Received: 07-03-2020

Accepted: 23-07-2020 